\title{
Selected adipose tissue hormones in the blood of patients with ischaemic cerebral stroke
}

\author{
Aleksandra Kazimierczak-Kabzińska' ${ }^{1}$, Dariusz Kajdaniuk2, Lucyna Siemińska' ${ }^{2}$ Mariusz Nowak², \\ Joanna Głogowska-Szeląg ${ }^{2}$, Halina Borgiel-Marek³, Szymon Janyga ${ }^{4}$, Beata Kos-Kudła², Bogdan Marek ${ }^{2}$
}

${ }^{1}$ Department of Neurology with Stroke Ward, Provincial Specialist Hospital, Betchatów, Poland

${ }^{2}$ Department of Pathophysiology and Endocrinology, Faculty of Medical Sciences in Zabrze, Medical University of Silesia, Katowice, Zabrze, Poland

${ }^{3}$ Department of Craniomaxillofacial and Oral Surgery, Faculty of Medical Sciences, Medical University of Silesia in Katowice, Katowice, Poland

${ }^{4}$ Department of Endocrinology and Metabolic Disorders, Provincial Specialist Hospital No. 3, Rybnik, Poland

\begin{abstract}
Introduction: Despite considerable progress in knowledge, ischaemic stroke is still a disease that causes serious clinical problems. A role in its pathogenesis can be attributed to i.a. adipose tissue hormones. The aim of this paper is to assess the blood levels of selected adipocytokines in patients during the acute phase of ischaemic stroke as compared to healthy persons, and an attempt to indicate a correlation between their blood concentrations and the level of stroke severity and its outcomes.

Material and methods: The study included 46 patients with fresh ischaemic stroke ( 27 females, 19 males, average age 67.6 years). All patients had a CT scan of the head, their neurological condition was assessed using a stroke severity scale, and their blood levels of resistin, chemerin, and visfatin were tested. The control group consisted of 32 patients (16 females, 16 males, average age 64.1 years) who had never suffered cerebrovascular diseases.

Results: Elevated levels of both resistin and chemerin were found in the group of patients with ischaemic stroke $(9.17 \pm 2.95 \mathrm{ng} / \mathrm{mL} v \mathrm{~s}$. $6.55 \pm 2.01 \mathrm{ng} / \mathrm{mL}$ for resistin and $265.0 \pm 59.3 \mathrm{ng} / \mathrm{mL} v s .191 .0 \pm 43.6 \mathrm{ng} / \mathrm{mL}$ for chemerin). It was also found that the blood concentration of chemerin was higher in females than in males with stroke. However, no difference was found in visfatin blood concentration between the group with ischaemic stroke and the control group $(1.65 \pm 1.09 \mathrm{ng} / \mathrm{mL}$ vs. $1.5 \pm 1.39 \mathrm{ng} / \mathrm{mL})$.

Conclusions: Higher resistin and chemerin blood concentrations significantly increase the risk of ischaemic stroke. The level of stroke severity at the moment of its occurrence and during its course do not depend on the concentrations of adipocytokines under analysis. (Endokrynol Pol 2020; 71 (1): 21-26)
\end{abstract}

Key words: ischaemic stroke; adipocytokines; resistin; chemerin; visfatin

\section{Introduction}

According to the WHO, strokes, along with cardiovascular diseases and cancer, are the leading causes of death for adults globally [1]. In Poland the deaths caused by stroke comprise a significant percentage of the total number of deaths [2]. It is estimated that over 60 thousand Polish inhabitants have an ischaemic stroke every year [3]. Currently, in Poland more than 400,000 persons suffer from permanent effects of stroke [2].

Over the last two decades, significant progress in treating ischaemic stroke has been made. Not only the comprehensive treatment in specialised stroke units but also thrombolytic treatment (recombinant tissue plasminogen activator - rt-PA, alteplase), the use of acetylsalicylic acid (ASA) within 24 hours of the stroke, and hemicraniectomy in selected cases are worth mentioning $[4,5]$.
Another problem is the stroke pathogenesis - it is still not fully explained. Adipose tissue is currently perceived not only as energy storage but also as an important endocrine organ secreting a number of adipocytokines that can affect the appetite, metabolic, endocrine, and immune body functions. Because of their multifunctional character, these substances have been a subject of research for many years. The interconnection between adipocytokines and ischaemic stroke as well as coronary disease, arterial hypertension, metabolic syndrome, and venous thrombosis was reported in many papers [6-8].

Resistin is produced by adipose tissue and blood macrophages. Its role is to increase the level of blood serum glucose and free fatty acids and inhibit glucose uptake by cells, which can increase insulin resistance (IR). Higher resistin levels are observed in obese individuals and people with type 2 diabetes [9]. The role of 
resistin in the pathogenesis of vascular diseases is still not fully explained; however, the majority of papers on the subject describe a relationship between resistin and the risk of cardiovascular (mainly coronary) incidents. So far, most authors emphasise the role of resistin in ischaemic stroke aetiology and prognosis [9-11].

Chemerin takes part in adipogenesis, adipose tissue regulation, and infiltrating adipose tissue by macrophages. It shows both anti-inflammatory and pro-inflammatory effects, i.e. it stimulates the chemotaxis of dendritic cells, macrophages, and natural killer (NK) cells to inflammatory foci and reduces the secretion of mediators and pro-inflammatory cytokines, including TNF- $\alpha$ and IL-6. It has been proven that chemerin affects the sensitivity of adipocytes to insulin and increases the insulin-stimulated glucose uptake by adipose tissue $[12,13]$.

Visfatin is produced both by adipocytes and macrophages. It stimulates the differentiation of preadipocytes to mature adipocytes and reduces the concentration of blood glucose (binding directly to the insulin receptor results in increased glucose uptake) without affecting insulinaemia [14]. The role of both chemerin and visfatin in the pathogenesis of ischaemic stroke is still not fully explained.

\section{Material and methods}

The study comprised 46 patients hospitalised at a Stroke Unit in the acute phase of ischaemic stroke (27 females and 19 males, 29 to 85 years of age, average age 67.6 years). Eligibility criteria were: confirmed ischaemic stroke with a neurological deficit lasting more than 24 hours, and the possibility of taking a blood sample for testing within 24 hours from the occurrence of stroke clinical symptoms. Exclusion criteria: haemorrhagic stroke, subarachnoid haemorrhage, brain tumour or any type of cancer, kidney/liver failure, severe infection, injury, surgery, myocardial infarction (MI) diagnosed over the last month, thyroid gland diseases diagnosed and treated, as well as diabetes in history.

The control group included 32 patients ( 16 females and 16 males, 30 to 86 years of age, average age 64.1) hospitalised at a neurology ward for back pain syndrome, who had never had a cerebral stroke or transient cerebral ischaemia (transient ischaemic attack) and who had not suffered any other chronic diseases except for arterial hypertension.

The Bioethics Committee operating at the Regional Medical Chamber in Łódź (K.B. No. -7/17 of 5 April 2017) granted permission to conduct the study.

Basic laboratory tests were performed for all patients: $C B C$, lipid profile [total cholesterol, low density lipoprotein (LDL), high density lipoprotein (HDL), triglycerides], electrolyte levels ( $\mathrm{Na}, \mathrm{K}, \mathrm{Mg}$, $\mathrm{Cl}$ ), TSH, fT3, fT4, CRP, creatinine, fasting glycaemia, and INR, and body mass index (BMI) was calculated. The severity of stroke was assessed in all patients by using the National Institutes of Health Stroke Scale (NIHSS) and Barthel Index (BI) for stroke severity (on day 1 and day 9 after the stroke onset), as well as the flows in intra- and extracranial arteries by using Doppler ultrasonography to detect any stenosis and intima-media (IT) thickness.

While taking a blood sample for basic biochemical tests (on day 1 after the occurrence of stroke symptoms) an additional full blood sample was taken of approx. $20 \mathrm{~mL}$ volume. The serum obtained after blood centrifugation was frozen at $-80^{\circ} \mathrm{C}$.
After collecting the whole material, the concentrations of selected adipose tissue hormones, i.e. resistin, chemerin, visfatin were determined. Tests were performed using commercially available immunoassays (BioVendor).

The database of clinical material was created by using a licensed version of Microsoft EXCEL spreadsheet v. 2010.

Statistical calculations were performed by using licensed statistical software packages. Statistica v. 7.1 PL supplied by StatSoft, MedCalc Statistical Software v. 14.10.2 and PQStat Software v. 1.6.6. During the statistical analysis, a significance level of $\mathrm{p}<0.05$ was assumed.

\section{Results}

The general characteristics of the study group and the control group did not show any significant statistical differences in terms of basic biochemical parameters and BMI. Only a higher percentage of patients with elevated fasting glycaemia and elevated CRP level as well as reduced potassium levels were found in the group with ischaemic stroke (Tab. 1).

The concentration of resistin in the study group ranged from 4.94 to $18.10 \mathrm{ng} / \mathrm{mL}$ with an average value of $9.17 \pm 2.95 \mathrm{ng} / \mathrm{mL}$, while in the control group it ranged from 3.28 to $13.23 \mathrm{ng} / \mathrm{mL}$ with an average value of $6.55 \pm 2.01 \mathrm{ng} / \mathrm{mL}$. The comparison of resistin concentration in both groups showed that in the cerebral stroke group the concentration of this adipocytokine was statistically significantly higher than in the control group $(\mathrm{p}<0.0001)$. Logistic regression allowed us to ascertain that resistin was a significant risk factor for stroke (Tab. 2, 3).

The concentration of chemerin in the study group ranged from 187.2 to $508.2 \mathrm{ng} / \mathrm{mL}$ with an average value of $265.0 \pm 59.3 \mathrm{ng} / \mathrm{mL}$, while in the control group it ranged from 134.1 to $319.1 \mathrm{ng} / \mathrm{mL}$ with an average value of $191.0 \pm 43.6 \mathrm{ng} / \mathrm{mL}$. The comparison of chemerin concentration between the groups showed that in the cerebral stroke group the concentration of this adipocytokine was statistically significantly higher than in the control group ( $p<0.0001)$. Logistic regression was used to confirm that chemerin was a significant risk factor for stroke. In addition, it was found that the concentration of chemerin was statistically significantly higher in females (average $279.4 \pm 68.87)$ than in males $(244.6 \pm 34.69)$ in the stroke group $(\mathrm{p}=0.0493)$ (Tab. 2, 3).

The concentration of visfatin in the study group ranged from 0.49 to $5.31 \mathrm{ng} / \mathrm{mL}$ with an average value of $1.65 \pm 1.09 \mathrm{ng} / \mathrm{mL}$, while in the control group it ranged from 0.22 to $6.77 \mathrm{ng} / \mathrm{mL}$ with an average value of $1.5 \pm 1.39 \mathrm{ng} / \mathrm{mL}$. No significant statistical difference in visfatin concentrations in both groups (Tab. 2) was found.

The study showed no correlation between the concentration of resistin, chemerin, and visfatin and the age of the study group. This correlation between the concentrations of adipocytokines and BMI was not found either (Tab. 4). 
Table 1. Characteristics of patients with ischaemic stroke and control group

\begin{tabular}{|c|c|c|c|}
\hline & $\begin{array}{l}\text { Ischaemic stroke } \\
\quad(n=46)\end{array}$ & $\begin{array}{c}\text { Control } \\
(n=32)\end{array}$ & $\begin{array}{c}\mathbf{p} \\
\text { value }\end{array}$ \\
\hline Age (years) & $\begin{array}{c}67.6 \\
(S D \pm 12.92)\end{array}$ & $\begin{array}{c}64.1 \\
(\mathrm{SD} \pm 64.1)\end{array}$ & 0.0851 \\
\hline $\begin{array}{l}\text { Total } \\
\text { cholesterol } \\
\text { [mg/dL] }\end{array}$ & $\begin{array}{c}186 \\
(S D \pm 55.52)\end{array}$ & $\begin{array}{c}195.6 \\
(S D \pm 35.77)\end{array}$ & 0.2161 \\
\hline $\mathrm{HDL}[\mathrm{mg} / \mathrm{dL}]$ & $\begin{array}{c}50.7 \\
(S D \pm 14.12)\end{array}$ & $\begin{array}{c}57.8 \\
(\mathrm{SD} \pm 11.28)\end{array}$ & 0.0093 \\
\hline LDL [mg/dL] & $\begin{array}{c}118.7 \\
(S D \pm 39.4)\end{array}$ & $\begin{array}{c}130.6 \\
(S D \pm 34.48)\end{array}$ & 0.1892 \\
\hline $\mathrm{TG}[\mathrm{mg} / \mathrm{dL}]$ & $\begin{array}{c}148.1 \\
(S D \pm 78.81)\end{array}$ & $\begin{array}{c}118.7 \\
(S D \pm 63.51)\end{array}$ & 0.1042 \\
\hline $\mathrm{Na}[\mathrm{mmol} / \mathrm{L}]$ & $\begin{array}{c}139.3 \\
(S D \pm 3.13)\end{array}$ & $\begin{array}{c}139.6 \\
(S D \pm 2.55)\end{array}$ & 0.6772 \\
\hline $\mathrm{K}[\mathrm{mmol} / \mathrm{L}]$ & $\begin{array}{c}3.93 \\
(S D \pm 0.45)\end{array}$ & $\begin{array}{c}4.22 \\
(S D \pm 0.47)\end{array}$ & 0.0078 \\
\hline $\mathrm{Mg}[\mathrm{mg} / \mathrm{dL}]$ & $\begin{array}{c}1.98 \\
(S D \pm 0.25)\end{array}$ & $\begin{array}{c}2.02 \\
(S D \pm 0.2)\end{array}$ & 0.1793 \\
\hline $\mathrm{Cl}[\mathrm{mmol} / \mathrm{L}]$ & $\begin{array}{c}102.7 \\
(S D \pm 4.25)\end{array}$ & $\begin{array}{c}103 \\
(S D \pm 3.2=19)\end{array}$ & 0.5681 \\
\hline $\begin{array}{l}\text { Creatine } \\
{[\mathrm{mg} / \mathrm{dL}]}\end{array}$ & $\begin{array}{c}0.88 \\
(S D \pm 0.28)\end{array}$ & $\begin{array}{c}0.76 \\
(S D \pm 0.19)\end{array}$ & 0.5681 \\
\hline TSH [ulU/mL] & $\begin{array}{c}1.72 \\
(S D \pm 1.69)\end{array}$ & $\begin{array}{c}1.29 \\
(S D \pm 0.94)\end{array}$ & 0.4951 \\
\hline fT3 [pg/dL] & $\begin{array}{c}2.68 \\
(\mathrm{SD} \pm 0.59)\end{array}$ & $\begin{array}{c}2.71 \\
(S D \pm 0.54)\end{array}$ & 0.7862 \\
\hline $\mathrm{fT} 4$ [ng/dL] & $\begin{array}{c}1.45 \\
(S D \pm 0.4)\end{array}$ & $\begin{array}{c}1.29 \\
(S D \pm 0.21)\end{array}$ & 0.1425 \\
\hline $\begin{array}{l}\text { Thrombocytes } \\
\text { [K/ul] }\end{array}$ & $\begin{array}{c}231 \\
(S D \pm 73)\end{array}$ & $\begin{array}{c}234.5 \\
(S D \pm 52.3)\end{array}$ & 0.4887 \\
\hline $\begin{array}{l}\text { Leukocytes } \\
\text { [K/ul] }\end{array}$ & $\begin{array}{c}8.63 \\
(S D \pm 2.43)\end{array}$ & $\begin{array}{c}8.05 \\
(S D \pm 2.55)\end{array}$ & 0.2223 \\
\hline $\mathrm{CRP}[\mathrm{mg} / \mathrm{dL}]$ & $\begin{array}{c}0.57 \\
(S D \pm 0.73)\end{array}$ & $\begin{array}{c}0.33 \\
(S D \pm 0.53)\end{array}$ & 0.0367 \\
\hline $\begin{array}{l}\text { Fasting } \\
\text { glycaemia } \\
{[\mathrm{mg} / \mathrm{dL}]}\end{array}$ & $\begin{array}{c}107.7 \\
(S D \pm 32.4)\end{array}$ & $\begin{array}{c}93.8 \\
(S D \pm 10.7)\end{array}$ & 0.0477 \\
\hline BMI & $\begin{array}{c}27.3 \\
(S D \pm 4.5)\end{array}$ & $\begin{array}{c}27.4 \\
(S D \pm 4.1)\end{array}$ & 0.9615 \\
\hline
\end{tabular}

HDL — high-density lipoprotein; LDL — low-density lipoprotein; TG — triglycerides; $\mathrm{Na}$ - sodium; $\mathrm{K}$ — potassium; $\mathrm{Mg}$ - magnesium; $\mathrm{Cl}$ - chlorine;

TSH — thyroid stimulating hormone; fT3 — triiodothyronine; fT4 — thyroxine

$\mathrm{CRP}$ - C-reactive protein; $\mathrm{BMI}$ — body mass index
Table 2. Resistin, chemerin, and visfatin in patients with ischaemic stroke and in the control group

\begin{tabular}{lccc}
\hline & $\begin{array}{c}\text { Ischaemic stroke } \\
(\mathbf{n}=\mathbf{4 6})\end{array}$ & $\begin{array}{c}\text { Control } \\
(\mathbf{n}=\mathbf{3 2})\end{array}$ & p value \\
\hline $\begin{array}{l}\text { Resistin } \\
{[\mathrm{ng} / \mathrm{mL}]}\end{array}$ & 9.17 & 6.55 & $<0.0001$ \\
\hline $\begin{array}{l}\text { Chemerin } \\
{[\mathrm{Sg} \pm 2.95)}\end{array}$ & 265.0 & $(\mathrm{SD} \pm 2.01)$ & \\
\hline $\begin{array}{l}\text { Visfatin } \\
{[\mathrm{ng} / \mathrm{mL}]}\end{array}$ & $(\mathrm{SD} \pm 59.3)$ & $(\mathrm{SD} \pm 43.6)$ & $<0.0001$ \\
\hline
\end{tabular}

No significant correlation between the concentrations of adipocytokines under analysis and the point values in Barthel scale on day 1 and day 9 from stroke and point values in NIH Stroke Scale in patients with ischaemic stroke was noticed (Tab. 5).

No correlation between resistin, chemerin, and visfatin concentration and the thickness of intima-media complex was noticed, no significant differences in concentration values of adipocytokines under analysis were found between patients with and without carotid artery stenosis (Tab. 6, 7).

\section{Discussion}

A prevailing majority of publications on the role of adipose tissue hormones in the development of vascular diseases deal with leptin and adiponectin, and a smaller number with resistin. Only a few papers analysing the possible role of other adipocytokines, i.a chemerin and visfatin, in ischaemic stroke pathogenesis have been published so far.

\section{Resistin}

Resistin is one of the best-known adipocytokines. Over the years its blood concentrations have been tested, and its role in the pathogenesis of obesity, arterial hypertension, cardiovascular diseases, and stroke has been studied [16, 17]. Qian et al. [18] showed a higher concentration of this adipocytokine in the blood of obese mice. In studies on human populations it was also found that the concentration of resistin often correlated with BMI and was higher in obese individuals

Table 3. Multifactorial logistic regression

\begin{tabular}{lccccc}
\hline & Coefficient & Standard error & $\mathbf{p}$ & Odds ratio & 95\% Cl \\
\hline Resistin & 0.3832 & 0.1612 & 0.0174 & 1.4669 & $1.0696-2.0119$ \\
\hline Chemerin & 0.0443 & 0.0123 & 0.0003 & 1.0453 & $1.0204-1.0707$ \\
\hline $\mathrm{Cl}-$ confidence interval; $\mathrm{p}<0.0001 ; \mathrm{R}^{2}{ }_{\text {Nagelere }}=0.6761$ & & & &
\end{tabular}


Table 4. Correlations of blood adipocytokines concentrations with body mass index (BMI) and age in patients with ischaemic stroke

\begin{tabular}{lcccccc}
\hline & \multicolumn{2}{c}{ Resistin $[\mathrm{ng} / \mathrm{mL}]$} & \multicolumn{2}{c}{ Chemerin $[\mathrm{ng} / \mathrm{mL}]$} & \multicolumn{2}{c}{ Visfatin [ng/mL] } \\
\hline & $\mathbf{R}$ & $\mathbf{p}$ value & $\mathbf{R}$ & $\mathbf{p}$ value & $\mathbf{R}$ & p value \\
\hline BMl & 0.1829 & 0.2786 & 0.060 & 0.715 & -0.0284 & 0.8696 \\
\hline Age & 0.0688 & 0.6495 & 0.0345 & 0.8200 & -0.1077 & 0.482 \\
\hline
\end{tabular}

$\mathrm{BMI}$ - body mass index

Table 5. Correlations of blood adipocytokines concentrations with National Institutes of Health Stroke Scale (NIHSS), and Barthel scale in patients with stroke

\begin{tabular}{lcccccc}
\hline & \multicolumn{2}{c}{ Resistin $[\mathrm{ng} / \mathrm{mL}]$} & \multicolumn{2}{c}{ Chemerin $[\mathrm{ng} / \mathrm{mL}]$} & \multicolumn{2}{c}{ Visfatin $[\mathrm{ng} / \mathrm{mL}]$} \\
\hline & $\mathbf{R}$ & $\mathbf{p}$ value & $\mathbf{R}$ & $\mathbf{p}$ value & $\mathbf{R}$ & $\mathbf{p}$ value \\
\hline NIHSS scale & 0.1912 & 0.2031 & 0.0735 & 0.6272 & 0.1015 & 0.5069 \\
\hline Barthel start & -0.2506 & 0.0929 & -0.0899 & 0.5526 & -0.0786 & 0.6079 \\
\hline Barthel end & -0.1792 & 0.2334 & -0.0526 & 0.7285 & -0.0867 & 0.5710 \\
\hline
\end{tabular}

NIHHS scale — scale of National Institutes of Health Stroke Scale; Barthel start — Barthel scale evaluation on admission; Barthel end — Barthel scale evaluation on ninth day following admission

Table 6. Correlations of blood adipocytokines concentrations with intima-media (IM) complex

\begin{tabular}{lcc}
\hline & \multicolumn{2}{c}{ IM complex } \\
\hline & R & p value \\
\hline Resistin $[\mathrm{ng} / \mathrm{mL}]$ & -0.0183 & 0.9094 \\
\hline Chemerin $[\mathrm{ng} / \mathrm{mL}]$ & 0.0219 & 0.8921 \\
\hline Visfatin $[\mathrm{ng} / \mathrm{mL}]$ & -0.0478 & 0.7698 \\
\hline
\end{tabular}

[19]. However, we did not observe this correlation, not only for resistin but also for chemerin and visfatin.

Reports on the role of resistin in arterial hypertension are contradictory. Some authors do not describe such correlations, but a study conducted in China including 1022 patients with diabetes showed a positive correlation between systolic blood pressure and the resistin gene polymorphism [20]. Bogański et al. [21] also confirm elevated adipocytokine levels in the group of patients with arterial hypertension.

Reports on the role of resistin in the pathogenesis of atherosclerosis are also sometimes contradictory. One study observed patients for six years, the tests were performed before and after ischaemic stroke or myocardial infarction. A positive correlation between the concentration of resistin and the incidence of myocardial infarction was shown; however, the same correlation for stroke was not observed. It should be emphasised that in the mentioned paper by Weikert et al. [22] the mechanism of stroke was embolic, which can be independent of chronic cerebrovascular disease. Another study including a numerous population of
Table 7. Resistin, chemerin, and visfatin levels in patients with ischaemic stroke with and without carotid artery stenosis in carotid Doppler ultrasonography

\begin{tabular}{lccc}
\hline & $\begin{array}{c}\text { Patients without } \\
\text { stenosis }(\mathbf{n}=\mathbf{3 6})\end{array}$ & $\begin{array}{c}\text { Patients with } \\
\text { stenosis }(\mathbf{n}=\mathbf{5})\end{array}$ & $\begin{array}{c}\mathbf{p} \\
\text { value }\end{array}$ \\
\hline $\begin{array}{l}\text { Resistin } \\
{[\mathrm{ng} / \mathrm{mL}]}\end{array}$ & $\begin{array}{c}9.8 \\
(\mathrm{SD} \pm 2.77)\end{array}$ & $\begin{array}{c}9.15 \\
(\mathrm{SD} \pm 3.15)\end{array}$ & 0.4972 \\
\hline $\begin{array}{l}\text { Chemerin } \\
{[\mathrm{ng} / \mathrm{mL}]}\end{array}$ & 243.80 & 266.85 & 0.4972 \\
\hline $\begin{array}{l}\text { Visfatin } \\
{[\mathrm{ng} / \mathrm{mL}]}\end{array}$ & 1.51 & $(\mathrm{SD} \pm 62.48)$ & \\
\hline
\end{tabular}

3201 individuals showed a correlation between elevated resistin levels and the frequency of ischaemic strokes, especially those with embolic and lacunar background. In this case a similar correlation was not shown for acute coronary syndromes and haemorrhagic strokes [23]. Perovic et al. [24] also confirmed the presence of higher resistin concentrations in patients with ischaemic stroke. Our study showed a significantly higher concentration of this adipocytokine in the group of patients with ischaemic stroke as compared to the control group. In addition, we found that resistin was an independent risk factor for ischaemic stroke; however, its blood concentration did not show any correlation with BMI (probably because patients under our analysis did not differ much in terms of body mass).

Despite the fact that we did not find any correlation of the intima-media (IM) complex thickness and the presence of carotid stenosis with resistin blood level, it should be emphasised that there are reports describing 
this correlation not only in patients with past ischaemic cerebral stroke but also in asymptomatic patients with unstable atherosclerotic plaque [25].

\section{Chemerin}

Chemerin is a pro-inflammatory adipokine, the amount of which in the blood is correlated with the inflammatory condition and the presence of metabolic syndrome [26]. Although knowledge on its pathogenetic role in the development of atherosclerosis is inferior to that of other adipocytokines, there are papers available in the literature that confirm the positive and negative correlation between chemerin blood concentration and the incidence of coronary artery disease [27, 28].

Information on patients with cerebral ischaemia is especially sparse. Analysis performed by Zoe et al. [29] to assess the correlation between the level of chemerin and ischaemic stroke and the occurrence of carotid atherosclerosis shows that chemerin detected in serum can be an independent risk factor for ischaemic stroke. The results of our study confirm this observation - the concentration of chemerin was significantly higher in patients with ischaemic stroke, especially (which is interesting) in females. Existing reports on the correlation between chemerin levels and the incidence of unstable atherosclerotic plaque are contradictory. A study on the Chinese population showed that chemerin was an independent risk factor for unstable carotid atherosclerotic plaques ( $p<0.05)$. On the other hand, there are also studies that contradict this. Our study does not show any correlation between chemerin blood level and the thickness of IM complex as well as the differences in chemerin concentration in patients with and without carotid stenosis.

\section{Visfatin}

The biological role of visfatin consists of differentiation of preadipocytes from adipocytes and a strong pro-inflammatory effect induced by activating leukocytes as well as stimulating the production of pro-inflammatory cytokines. By binding to insulin receptor, visfatin has a hypoglycaemic effect [31].

Visfatin has been described as a prognostic factor for death in cardiovascular diseases. Its high level was noticed in patients with acute myocardial infarction and obese patients with metabolic syndrome $[32,33]$. In the past there were also studies and papers describing the role of visfatin in acute ischaemic stroke. The majority of papers showed that its blood levels in patients with ischaemic cerebral stroke were elevated [34, 35]. Our observations do not confirm this correlation. However, it should be emphasised that the groups were uniform in terms of BMI.

Kadoglou et al. [35], in contrast to us, described higher visfatin serum levels in patients with acute ischaemic stroke and carotid stenosis (> 50\%). Studies conducted by other authors show that high blood visfatin levels seem to be strongly correlated with the presence and intensity of atherosclerotic lesions in peripheral blood vessels [36].

\section{Adipocytokines vs. clinical course of a stroke}

In literature there are only isolated reports on the mutual correlation between the concentrations of some adipocytokines and the course of a stroke. Studies show a positive correlation between the adiponectin concentration and the severity of a stroke, but some studies do not confirm this, and may even contradict it $[37,38]$.

Efstathiou et al. [39] showed a worse course of ischaemic stroke and a higher death rate in patients with high resistin blood level, which was not confirmed in studies conducted by Bienek et al. [25, 29, 38]. Our study did not confirm this correlation either. Currently there are no similar studies for chemerin and visfatin available in the literature. Our analysis does not confirm the correlation between the course of stroke and the level of chemerin and visfatin in blood. However, it seems that this assessment requires a study covering a considerably larger population.

\section{Conclusions}

The role of adipose tissue hormones in ischaemic stroke is relatively poorly recognised. There are only a few publications available that show contradictory results, and usually refer to relatively small groups of patients.

The higher level of resistin and chemerin in the blood of patients with ischaemic stroke observed in our study are partially convergent with the studies conducted by other authors, which leads us to suspect that there is a pathogenetic connection between them and the risk factor for ischaemic stroke.

By contrast, the analysis of visfatin did not confirm its higher concentration in patients with ischaemic stroke, which was unexpected.

The lack of correlation between the concentrations of the adipocytokines under analysis (especially resistin) and BMI is also surprising; however, it should be noted that the patients under analysis were uniform in terms of their body mass, and in general they were not obese.

No correlation between the levels of resistin, chemerin, and visfatin and the severity of stroke at the moment of its occurrence and its course was found.

\section{Funding}

Information on grants and other funding sources: KNW 1-080/N-8-0. 


\section{References}

1. WHO: The Atlas of Heart Disease and Stroke: Global burden of stroke. http://www.who.int/cardiovascular_diseases/resources/atlas/en.

2. Grabowska-Fudala B, Jaracz K, Górna K. [Stroke incidence, case fatality and mortality — current trends and future prognosis]. Przegl Epidemiol. 2010; 64(3): 439-442, indexed in Pubmed: 20976960.

3. Członkowska A, Ryglewicz D. Epidemiologia udarów mózgu w Polsce. Neurol Neurochir Pol. 1999; 32(Suppl 6): 99-103, indexed in Pubmed: 11107570.

4. Powers WJ, Rabinstein AA, Ackerson T, et al. American Heart Association Stroke Council. 2018 Guidelines for the Early Management of Patients With Acute Ischemic Stroke: A Guideline for Healthcare Professionals From the American Heart Association/American Stroke Association. Stroke. 2018; 49(3): e46-e4e110, doi: 10.1161/STR.0000000000000158, indexed in Pubmed: 29367334.

5. Alper BS, Malone-Moses M, McLellan JS, et al. Thrombolysis in acute ischaemic stroke: time for a rethink? BMJ. 2015; 350: h1075, doi: 10.1136/bmj.h1075, indexed in Pubmed: 25786912.

6. Kershaw EE, Flier JS. Adipose tissue as an endocrine organ. J Clin Endocrinol Metab. 2004; 89(6): 2548-2556, doi: 10.1210/jc.2004-0395, indexed in Pubmed: 15181022

7. Meier U. Endocrine Regulation of Energy Metabolism: Review of Pathobiochemical and Clinical Chemical Aspects of Leptin, Ghrelin, Adiponectin, and Resistin. Clinical Chemistry. 2004; 50(9): 1511-1525, doi: 10.1373/clinchem.2004.032482, indexed in Pubmed: 15265818.

8. Machura E, Szczepańska M, Świętochowska E, et al. Evaluation of adipokines in children with cystic fibrosis. Endokrynol Pol. 2018; 69(2): 128-134, doi: 10.5603/EP.a2018.0007, indexed in Pubmed: 29465158.

9. Reilly MP, Lehrke M, Wolfe ML, et al. Resistin is an inflammatory marker of atherosclerosis in humans. Circulation. 2005; 111(7): 932-939, doi: 10.1161/01.CIR.0000155620.10387.43, indexed in Pubmed: 15710760.

10. Osawa H, Doi Y, Makino H, et al. Diabetes and hypertension markedly increased the risk of ischemic stroke associated with high serum resistin concentration in a general Japanese population: the Hisayama Study. Cardiovasc Diabetol. 2009; 8: 60, doi: 10.1186/1475-2840-8-60, indexed in Pubmed: 19922611.

11. Weikert $C$, Westphal S, Berger $K$, et al. Plasma resistin levels and risk of myocardial infarction and ischemic stroke. J Clin Endocrinol Metab. 2008; 93(7): 2647-2653, doi: 10.1210/jc.2007-2735, indexed in Pubmed: 18460562.

12. Olszanecka-Glinianowicz M, Kocełak P, Orlik B, et al. Nowe adipokiny - korzystne czy niekorzystne $\mathrm{w}$ aspekcie patogenezy insulinooporności? Endokrynol Otył Zab Przem Mat. 2009; 5: 236-242.

13. Kaur J, Mattu H, Chatha K, et al. Chemerin in human cardiovascular disease. Vascul Pharmacol. 2018; 110: 1-6, doi: 10.1016/j.vph.2018.06.018, indexed in Pubmed: 30016719.

14. Cybulska B. Wisfatyna - co dotychczas wiadomo o jej roli w fizjologii i patologii? Komentarz redakcyjny. Kardiol Pol. 2011; 69(8): 808-809.

15. Prugger C, Luc G, Haas B, et al. PRIME Study Group. Adipocytokines and the risk of ischemic stroke: the PRIME Study. Ann Neurol. 2012; 71(4): 478-486, doi: 10.1002/ana.22669, indexed in Pubmed: 22522440.

16. Denes J, Zsippai A, Kovacs L, et al. Comparison of adipose tissue derived genes in endogenous Cushing's syndrome versus diet-induced obesity. Endokrynol Pol. 2019; 70(2): 131-134, doi: 10.5603/EP.a2018.0091, indexed in Pubmed: 30480750.

17. Dyaczyński M, Scanes CG, Koziec H, et al. Endocrine implications of obesity and bariatric surgery. Endokrynol Pol. 2018; 69(5): 574-597, doi: 10.5603/EP.2018.0059, indexed in Pubmed: 30379322

18. Qian H, Gingerich R, Mistry J. Differences in the expression pattern of resistin protein in the serum and adipose tissueof ob/ob mice. Diabetes. 2003; 52: A86-A87.

19. Way JM, Görgün $C Z$, Tong $Q$, et al. Adipose tissue resistin expression is severely suppressed in obesity and stimulated by peroxisome proliferator-activated receptor gamma agonists. J Biol Chem. 2001; 276(28): 25651-25653, doi: 10.1074/jbc.C100189200, indexed in Pubmed: 11373275.

20. CaoH,Hegele RA. Single nucleotide polymorphisms of the resistin (RSTN) gene. J Hum Genet. 2001; 46(9): 553-555, doi: 10.1007/s100380170040, indexed in Pubmed: 11558907.

21. Bogdański P, Musialik K, Szulińska M, et al. Ocena stężenia rezystyny u pacjentów z nadciśnieniem tẹtniczym i zespołem metabolicznym. Endokrynol Otył Zab Przem Mat. 2006; 2(4): 116-121.
22. Weikert C, Westphal S, Berger K, et al. Plasma resistin levels and risk of myocardial infarction and ischemic stroke. J Clin Endocrinol Metab. 2008; 93(7): 2647-2653, doi: 10.1210/jc.2007-2735, indexed in Pubmed: 18460562

23. Tsukahara T, Nakashima E, Watarai A, et al. Polymorphism in resistin promoter region at -420 determines the serum resistin levels and may be a risk marker of stroke in Japanese type 2 diabetic patients. Diabetes Res Clin Pract. 2009; 84(2): 179-186, doi: 10.1016/j.diabres.2008.10.021, indexed in Pubmed: 19269054.

24. Perovic E, Mrdjen A, Harapin M, et al. Diagnostic and prognostic role of resistin and copeptin in acute ischemic stroke. Top Stroke Rehabil. 2017; 24(8): 614-618, doi: 10.1080/10749357.2017.1367454, indexed in Pubmed: 28845746.

25. Jurin I, Paić F, Bulimbašić S, et al. Association between Circulatory and Plaque Resistin Levels with Carotid Plaque Instability and Ischemic Stroke Events. Heart Surg Forum. 2018; 21(6): E448-E463, doi: 10.1532/hsf.2071, indexed in Pubmed: 30604667.

26. Li Ya, Shi B, Li S. Association between serum chemerin concentrations and clinical indices in obesity or metabolic syndrome: a meta-analysis. PLoS One. 2014; 9(12): e113915, doi: 10.1371/journal.pone.0113915, indexed in Pubmed: 25469985.

27. Xiaotao Li, Xiaoxia Z, Yue X, et al. Serum chemerin levels are associated with the presence and extent of coronary artery disease. Coron Artery Dis. 2012; 23(6): 412-416, doi: 10.1097/MCA.0b013e3283576a60, indexed in Pubmed: 22828724.

28. Kaur J, Mattu HS, Chatha K, et al. Chemerin in human cardiovascular disease. Vascul Pharmacol. 2018; 110: 1-6, doi: 10.1016/j.vph.2018.06.018, indexed in Pubmed: 30016719.

29. Zhao D, Bi G, Feng J, et al. Association of Serum Chemerin Levels with Acute Ischemic Stroke and Carotid Artery Atherosclerosis in a Chinese Population. Med Sci Monit. 2015; 21: 3121-3128, doi: 10.12659/msm.895866, indexed in Pubmed: 26471865.

30. Gasbarrino K, Mantzoros C, Gorgui J, et al. Circulating Chemerin Is Associated With Carotid Plaque Instability, Whereas Resistin Is Related to Cerebrovascular Symptomatology. Arterioscler Thromb Vasc Biol. 2016; 36(8): 1670-1678, doi: 10.1161/ATVBAHA.115.306741, indexed in Pubmed: 27312219

31. Fukuhara A, Matsuda M, Nishizawa M, et al. Visfatin: a protein secreted by visceral fat that mimics the effects of insulin. Science. 2005; 307(5708): 426-430, doi: 10.1126/science.1097243, indexed in Pubmed: 15604363.

32. Mazaherioun M, Hosseinzadeh-Attar MJ, Janani L, et al. Elevated serum visfatin levels in patients with acute myocardial infarction. Arch Iran Med. 2012; 15(11): 688-692, doi: 0121511/AIM.008, indexed in Pubmed: 23102245

33. Zahorska-Markiewicz B, Olszanecka-Glinianowicz M, Janowska J, et al. Serum concentration of visfatin in obese women. Metabolism. 2007; 56(8): 1131-1134, doi: 10.1016/j.metabol.2007.04.007, indexed in Pubmed: 17618961.

34. Ilhan N, Susam S, Canpolat O, et al. The emerging role of leptin, Adiponectin and Visfatin in Ischemic/Hemorrhagic stroke. Br J Neurosurg. 2019; 33(5): 504-507, doi: 10.1080/02688697.2019.1578862, indexed in Pubmed: 30892950

35. Kadoglou NPE, Fotiadis G, Lambadiari V, et al. Serum levels of novel adipokines in patients with acute ischemic stroke: potential contribution to diagnosis and prognosis. Peptides. 2014; 57: 12-16, doi: 10.1016/j. peptides.2014.04.008, indexed in Pubmed: 24768795.

36. Pitoulias MG, Skoura L, Pitoulias AG, et al. The role of Visfatin in atherosclerotic peripheral arterial obstructive disease. Cytokine. 2017; 91: 140-144, doi: 10.1016/j.cyto.2016.12.027, indexed in Pubmed: 28073026.

37. Marousi SG, Theodorou GL, Karakantza M, et al. Acute post-stroke adiponectin in relation to stroke severity, progression and 6 month functional outcome. Neurol Res. 2010; 32(8): 841-844, doi: 10.1179/0161 64109X12581096796477, indexed in Pubmed: 20021741.

38. Bienek R, Marek B, Kajdaniuk D, et al. Adiponectin, leptin, resistin and insulin blood concentrations in patients with ischaemic cerebral stroke. Endokrynol Pol. 2012; 63(5): 338-345, indexed in Pubmed: 23115066.

39. Efstathiou SP, Tsiakou AG, Tsioulos DI, et al. Prognostic significance of plasma resistin levels in patients with atherothrombotic ischemic stroke. Clin Chim Acta. 2007; 378(1-2): 78-85, doi: 10.1016/j.cca.2006.10.023, indexed in Pubmed: 17173885. 